\title{
PENDIDIKAN KARAKTER: \\ Sebuah Upaya Pembentuk Karakter Bangsa
}

Oleh: Reza Ahmad Zahid*

\begin{abstract}
Abstrak
Tulisan ini mengkaji tentang konsep Pendidikan Karakter. Konsep ini masih menarik dikaji dan diketengahkan lagi karena kendatipun ia telah lama dicetuskan dan diserukan oleh Pemerintah untuk diimplementasikan di seluruh satuan pendidikan, namun pada realitanya masih banyak bermunculan fenomena-fenomena yang bertolak belakang dengan nilai-nilai yang diperjuangkan dalam Pendidikan Karakter.

Konsep Pendidikan Karakter yang diupayakan oleh Pemerintah Indonesia, menurut hemat penulis, sudah sangat ideal. Namun, nampaknya, pada realitanya, masih bersifat sangat teoritis. Padahal, suatu karakter tidak bias dibentuk hanya dengan teori, tetapi harus turun pada praksis. Selain itu, konsep ini juga tidak akan berjalan dan menghasilkan hasil yang sempurna jika tidak ada kerjasama yang baik antara sekolah, keluarga, lingkungan/ masyarakat, dan juga pemerintah.
\end{abstract}

Key Words: Pendidikan Karakter, Pemerintah, Akhlak

\section{Pendahuluan}

Bila kita menyaksikan persaingan antar lembaga pendidikan di Indonesia seakan-akan tidak ada bedanya dengan persaingan bisnis. Bagaimana tidak, gedung mewah serta fasilitas wah sudah menjadi sasaran empuk para orang tua untuk menyekolahkan anaknya di tempat tersebut. Ironisnya, lembaga pendidikan yang hanya bermodal pas-pasan serta berfasilitas ala kadarnya selalu mengalami keterpurukan yang istiqomah dan berkelanjutan. Demikian juga para calon pelajar selalu mengedepankan penilaian tentang bagaimana gedungnya,

*Institut Agama Islam Tribakti (IAIT) Kediri.

Volume 24 Nomor 2 September 2013 
bagaimana tamannya, bagaimana fasilitasnya, dan bahkan bagaimana para pelajarnya tentang tingkat ekonominya. Selain itu, para pelajar juga selalu mengedepankan pertanyaan; bagaimana nanti setelah keluar dari lembaga ini? Apakah saya langsung mendapatkan pekerjaan atau tidak?

Gambaran diatas sangatlah wajar dan sekali sangat wajar untuk menjadi pertimbangan dunia pendidikan di sebuah negara. Pendidikan maju berarti fasilitas serta sarana dan prasarana lembaga pendidikan haruslah maju pula. Pendidikan yang nyaman berarti fasilitas nyaman serta berani menjanjikan output yang nyaman pula bagi para pelajarnya dan alumnusnya. Adapun yang tidak wajar adalah mengedepankan fasilitas akan tetapi meninggalkan kualitas pendidikan pada lembaga pendidikan. Sangat tidak wajar ketika sebuah lembaga hanya memajukan fasilitas atau sarana prasarana lembaga akan tetapi tidak memajukan kualitas pengajar, staf/karyawan dan seluruh fungsionaris yang terlibat dalam civitas akademika sebuah lembaga pendidikan. Demikian juga sebagai pelajar sangat tidak wajar jika hanya mengedepankan rasa nyaman ketika berada di kampus akan tetapi tidak memikirkan keseriusan dalam belajar. Sangat tidak wajar ketika seorang pelajar hanya memikirkan perasaan enjoy di kampus tapi tidak berpikir untuk ke-enjoy-an masa depannya.

Bila kita remehkan kandungan paragrap kedua ini, maka yang akan terjadi adalah menyebarnya virus kapitalisme hedonistik dalam dunia pendidikan Indonesia. Kapitalisme dalam dunia pendidikan sebenarnya adalah sikap pemanjaan terhadap pelajar. Sedikit demi sedikit maindset mereka akan berubah. Mereka akan selalu mementingkan packaging daripada content, mereka akan mengutamakan kuantitas daripada kualitas dan yang lebih parah lagi ketika mereka lebih mengedepankan instant daripada proses.

Entah apa yang harus kita katakan ketika melihat tingkah laku orang-orang yang mengatakan dirinya sebagai orang yang terpelajar. Diantara contoh nyata adalah mereka menyebut dirinya sebagai hamba Tuhan akan tetapi mereka tidak menjalankan nilai-nilai yang ditetapkan oleh Tuhannya. Mereka tahu bahwa dirinya adalah manusia akan tetapi mereka berkelakuan tidak seperti tingkah laku manusia. Mereka 
mengatakan dirinya manusia tapi tidak bisa memanusiakan manusia. Mereka memiliki jiwa dan raga tapi ironisnya mereka tidak mengetahui jati dirinya. Sungguh naif nasib negara ini, bagaimana mungkin dia akan mengetahui jati diri bangsa dan negara bila bangsanya tidak mengetahui jati dirinya masingmasing.

Entah apa yang hilang dari bangsa ini ketika kita melihat pola komunikasi dan interaksi sosial bangsa ini. Tidak sedikit dari generasi bangsa telah melupakan pola-pola sosial yang telah dibangun oleh para leluhur mereka. Ada pola-pola baru yang hadir di tengah generasi bangsa. Mereka merasa kesulitan untuk membedakan mana yang positif dan mana yang negative, ketika mereka bergaul dengan sahabat atau masyarakat di sekelilingnya. Dalam hal komunikasi, mereka memilki pola yang baru ketika mereka berkomunikasi dengan keluarga dan masyarakat. Hal ini tampak dari tidak adanya perbedaan dalam komunikasi, mana orang tua dan mana teman, mana saudara/i dan mana pacar.

Entah, ada apa dengan moral generasi bangsa ini. Mereka lupa dengan sila pertama dan sila terakhir dalam ideologi bangsa ini yakni Pancasila. Tingkah laku yang tidak mencerminkan manusia yang berketuhanan dapat kita saksikan setiap hari disekitar kita. Tingkah laku yang tidak mencerminkan akan manusia yang beradab dan bermoral menjadi tontonan kita setiap hari. Padahal, sejarah bangsa ini membuktikan bahwa mereka adalah bangsa yang bermartabat tinggi karena moralitas dan peradaban yang mereka miliki. Bangsa ini telah lama sejak sebelum dilahirkan negara ini telah menjunjung tinggi akan agama.

Entah bagaimana nasib harkat dan martabat bangsa ini, kita adalah bangsa yang besar, negara yang luas, kaya dengan sumber daya alam yang melimpah dari ujung sampai ke ujung negeri ini. Akan tetapi kenapa kita tidak bisa menguasai dunia dari berbagai aspek, aspek ekonomi, politik, pendidikan, teknologi, dan lain sebagainya.

Hal-hal tersebut diatas adalah sebagian kecil dari contohcontoh perubahan karakter bangsa. Tentu saja sudah menjadi sebuah keharusan bagi kaum akademisi dan kaum terpelajar untuk mengevaluasi kejadian disekitar dan menemukan solusi 
agar bangsa ini tidak semakin terpuruk dalam karakter yang dapat membunuh karakter sejati bangsa ini. Pendidikan Karakter adalah solusi yang ditawarkan oleh pemerintah untuk mengatasi konteks disorientasi bangsa ini.

\section{Pendidikan Karakter}

Secara umum, Pendidikan Karakter memiliki grand design sebuah proses pembudayaan dan pemberdayaan nilai-nilai luhur dalam lingkungan satuan pendidikan, lingkungan keluarga, dan lingkungan masyarakat (Koentjaraningrat,2002). ${ }^{\dagger}$ Proses yang dikemukakan ini setidaknya searah dengan definisi karakter itu sendiri. Secara bahasa, kata karakter berasal dari bahasa latin 'character', yang dalam Kamus Besar Bahasa Indonesia (KBBI) diartikan sebagai: watak, tabiat, sifat-sifat kejiwaan, budi pekerti, kepribadian atau akhlak yang membedakan seseorang dengan yang lain (Depdiknas, 2008). Sedangkan secara istilah, masih menurut KBBI, karakter diartikan sebagai sifat manusia pada umumnya dimana manusia mempunyai banyak sifat yang tergantung dari faktor kehidupannya sendiri (Depdiknas, 2008). Lebih lengkapnya lagi, Azimabadi Badr dalam Etiquettes of Islamic Life mendefinisikan karakter berikut:

'karakter merupakan nilai-nilai perilaku manusia yang berhubungan dengan Tuhan yang maha Esa, diri sendiri, sesama manusia, lingkungan, dan kebangsaan yang terwujud dalam pikiran, sikap, perasaan, perkataan, dan perbuatan berdasarkan norma-norma agama, hukum, tata krama, budaya dan adat istiadat.' (Azimabadi Badr, 2000).

Dengan dasar ini, maka seseorang bias dikatakan berkarakter jika orang tersebut memiliki watak, tabiat, sifat kejiwaan, budi pakerti, kepribadian, atau akhlak, baik itu yang berhubungan dengan Tuhan, diri sendiri, sesama manusia, lingkungan maupun kebangsaan, dan kesemuanya itu bersifat khas. Maksudnya, hal-hal itu sudah melekat pada diri orang tersebut dan sudah menjadi ciri khas dirinya. Ciri khas ini bisa ia dapat melalui internalisasi dari sekitarnya, seperti keluarga,

\footnotetext{
${ }^{\dagger} 147$
} 
lingkungan, adat kebudayaan, sekolahan, maupun ajaran agama, dan juga dari bawaan dari lahirnya (Doni Koesoema, 2007).

Disamping itu semua, pendidikan sendiri berarti sebuah usaha yang dilakukan oleh seseorang/ kelompok/ masyarakat/ lembaga untuk membantu peserta didik dalam mengembangkan potensi - potensi yang dimilikinya (YB. Mangunwijaya, 2005). Dengan demikian, maksud dari Pendidikan Karakter adalah upaya sadar seseorang/ kelompok/ masyarakat/ lembaga untuk menanamkan nilai-nilai luhur tersebut kepada segenap anak didik hingga nilai-nilai tersebut melekat dan menjadi karakter khas atau watak kebribadian mereka. Hal ini diharapkan anak didik mampu mengimplementasikan nilai-nilai luhur tersebut dalam kehidupan mereka sehari hari, baik kepada Tuhan, dirinya sendiri, sesama manusia, lingkungan, maupun bangsa.

\section{Karakter yang Hendak diInternalisasikan}

Grand design yang ditawarkan oleh Pendidikan Karakter ini sebenarnya berdasarkan pada nilai-nilai luhur dari teori-teori pendidikan, psikologi pendidikan, nilai-nilai sosial budaya, ajaran agama, Pancasila, UUD 1945, dan UU nomor 20 tahun 2003 tentang Sistem Pendidikan Nasional, serta pengalaman terbaik dan praktik nyata dalam kehidupan sehari-hari (Kopertais IV, 2012). Dengan kata lain, karakter atau nilai-nilai luhur yang akan diinternalisasikan kepada anak didik dalam proses pendidikan adalah nilai-nilai luhur tersebut.

Namun, penjelasan tersebut masih bersifat sangat abstrak. Oleh karena itu, untuk mempermudah implementasi, Kementerian Pendidikan Nasional melalui Badan Penelitian dan Pengembangan serta Pusat Kurikulum dan Perbukuan membuat sebuah buku panduan yang di dalamnya dijelaskan secara rinci nilai-nilai luhur yang akan diinternalisasikan. Nilai-nilai tersebut diidentifikasi terdapat 18 nilai, yakni: religius, jujur, toleransi, disiplin, kerja keras, kreatif, mandiri, demokratis, rasa ingin tahu, semangat kebangsaan, cinta tanah air, menghargai prestasi, bersahabat/ komunikatif, cinta damai, gemar membaca, peduli lingkungan, peduli sosial, dan tanggung jawab.

Lebih lanjut, dalam buku pedoman tersebut dijelaskan bahwa rumusan 18 nilai itu tidak semuanya harus diaplikasikan oleh suatu satuan pendidikan. Namun, setiap satuan pendidikan 
dapat menentukan prioritas pengembangannya dengan dasar melanjutkan nilai-nilai prakondisi yang telah lama dikembangkan (Kemendiknas, 2011).

Setiap satuan pendidikan, sebetulnya, jauh sebelum program pendidikan karakter dicetuskan, selama ini sudah mengembangkan dan melaksanakan nilai-nilai pembentuk karakter melalui program operasional satuan pendidikan. Inilah yang disebut dengan prakondisi pendidikan karakter, dan setiap satuan pendidikan memiliki prioritas nilai yang berbeda-beda. Oleh karena itu, rumusan 18 nilai tersebut bisa dipilih dan dipilah sesuai situasi dan nilai prakondisi yang telah lama dikembangkan. Dengan demikian, dalam implementasinya dimungkinkan terdapat perbedaan mengenai jenis nilai karakter yang dikembangkan antara satu sekolah dan atau daerah yang satu dengan lainnya.

\section{Proses Implementasi}

Proses implementasi pendidikan karakter didasarkan pada totalitas psikologis anak didik dan fungsi totalitas sosiokultural pada konteks interaksi. Totalitas psikologis mencakup seluruh potensi anak didik, baik kognitif, afektif, maupun psikomotorik. Sedangkan fungsi totalitas sosiokultural mencakup semua interaksi anak didik, baik dalam keluarga, satuan pendidikan maupun masyarakat. Pendasaran ini dilakukan karena pada hakekatnya perilaku seseorang yang berkarakter merupakan implementasi dari kedua fungsi totalitas tersebut (Kemendiknas, 2011).

Konfigurasi karakter dalam konteks totalitas psikologis dan sosiokultural dapat dikelompokkan menjadi empat, yaitu: 1) olah pikir; 2) olah hati; 3) olah raga; dan 4) olah rasa dan karsa. Perlu diketengahkan bahwa masing-masing komponen ini secara konseptual merupakan gugus yang di dalamnya terkandung sejumlah nilai luhur. Perinciannya adalah sebagaimana berikut:

1. Olah Pikir

Komponen ini mengandung nilai-nilai luhur seperti: cerdas, kritis, kreatif, inovatif, ingin tahu, berpikir terbuka, produktif, berorientasi Iptek, dan reflektif. 
2. Olah Hati

Komponen ini mengandung nilai-nilai luhur seperti: beriman dan bertakwa, jujur, amanah, adil, bertanggung jawab, berempati, berani mengambil resiko, pantang menyerah, rela berkorban, dan berjiwa patriotic.

3. Olah Raga

Komponen ini mengandung nilai-nilai luhur seperti: bersih dan sehat, disiplin, sportif, tangguh, andal, berdaya tahan, bersahabat, kooperatif, determinatif, kompetitif, ceria, dan gigih.

4. Olah Rasa dan Karsa

Komponen ini mengandung nilai-nilai luhur seperti: ramah, saling menghargai, toleran, peduli, suka menolong, gotong royong, nasionalis, kosmopolit, mengutamakan kepentingan umum, bangga menggunakan bahasa dan produk Indonesia, dinamis, kerja keras, dan beretos kerja. (Kemendiknas, 2011).

Keempat hal ini berproses secara holistik dan koheren. Dengan kata lain masing-masing dari keempat komponen tersebut memiliki saling keterkaitan dan saling melengkapi, tidak berjalan sendiri-sendiri.

Kemudian, terkait strategi implementasi di satuan pendidikan, Kemendiknas memberikan panduan langkahlangkah sebagai berikut: Pertama, sosialisasi kepada stakeholders yang meliputi Komite sekolah, masyarakat, dan lembaga-lembaga; Kedua, mengembangan kurikulum yang berbasis pendidikan karakter. Misalnya sebagaimana table berikut:

\begin{tabular}{|c|l|l|}
\hline 1. & $\begin{array}{l}\text { Integrasi dalam } \\
\text { Mata Pelajaran }\end{array}$ & $\begin{array}{l}\text { Mengembangkan Silabus dan RPP } \\
\text { pada kompetensi yang telah ada } \\
\text { sesuai dengan nilai yang akan } \\
\text { diterapkan. }\end{array}$ \\
\hline 2. & $\begin{array}{l}\text { Integrasi dalam } \\
\text { Muatan Lokal }\end{array}$ & $\begin{array}{l}\text { Ditetapkan Oleh Satuan } \\
\text { Pendidikan/ Daerah } \\
\text { - Kompetensi dikembangkan oleh } \\
\text { Satuan Pendidikan/ Daerah }\end{array}$ \\
\hline
\end{tabular}

Volume 24 Nomor 2 September 2013 


\begin{tabular}{|c|c|c|}
\hline 3. & $\begin{array}{l}\text { Kegiatan } \\
\text { Pengembangan } \\
\text { Diri }\end{array}$ & $\begin{array}{l}\text { Pembudayaan dan Pembiasaan } \\
\text { - Pengondisian } \\
\text { - Kegiatan rutin } \\
\text { - Kegiatan spontanitas } \\
\text { - Keteladanan } \\
\text { - Kegiatan terprogram } \\
\text { - Ekstrakurikuler } \\
\text { Kegiatan-kegiatan seperti: } \\
\text { Pramuka; PMR; UKS; Olah } \\
\text { Raga; Seni; OSIS } \\
\text { Bimbingan Konseling } \\
\text { Pemberian layanan bagi peserta } \\
\text { didik yang mengalami masalah }\end{array}$ \\
\hline
\end{tabular}

Tabel dikutip dari (Kemendiknas, 2011).

Ketiga, kegiatan pembelajaran. Guna pengembangan karakter anak didik kegiatan pembelajaran dapat menggunakan pendekatan belajar aktif seperti pendekatan belajar kontekstual, pembelajaran kooperatif, pembelajaran berbasis masalah, pembelajaran berbasis proyek, pembelajaran pelayanan, pembelajaran berbasis kerja, dan ICARE (Introduction, Connection, Application, Reflection, Extension).

Keempat, Pengembangan Budaya Sekolah dan Pusat Kegiatan Belajar. Langkah ini meliputi: 1) kegiatan rutin, yaitu kegiatan yang dilakukan anak didik secara terus-menerus dan konsisten setiap saat, misalnya Upacara hari senin dan berdo'a sebelum dan sesudah belajar; 2) kegiatan spontan, yaitu kegiatan yang dilakukan anak didik secara spontan pada saat itu juga, misalnya mengumpulkan sumbangan untuk temennya yang sakit atau ada bencana; 3) keteladanan, yaitu guru, tenaga kependidikan dan anak didik harus bersikap memberi tauladan bagi yang lain; 4) pengondisian, yaitu menciptakan kondisi yang mendukung keterlaksanaan pendidikan karakter, misalnya kebersihan badan dan pakaian, toilet, tempat sampah dan lainlain; 5) kegiatan ko-kurikuler atau ekstrakurikuler. Kegiatan ini bias dijadikan media internalisasi nilai-nilai pendidikan karakter dengan tidak disadari oleh anak didik; dan 6) kegiatan keseharian di rumah dan di masyarakat. Hal ini dapat 
diwujudkan dengan, misalnya, sekolah membuat angket berkenaan nilai yang dikembangkan di sekolah dengan responden keluarga dan lingkungan sekitar. Ini ditujukan sepaya tercipta keselarasan antara karakter yang dikembangkan di sekolah dengan pembiasaan di rumah dan masyarakat. (Kemendiknas, 2011).

Seandainya waktu wajib belajar tidak cukup, satuan pendidikan dapat membuat kebijakan penambahan alokasi waktu. Misalnya, jika masuk KBM pukul $07.00 \mathrm{Wib}$, anak didik bias disuruh hadir sebelum itu dan diisi, misalnya, membaca kitab suci bersama-sama, dan/ atau hal ini dilakukan setelah selesai KBM.

Jika semua langkah atau proses implementasi pendidikan karakter tersebut telah berjalan, maka langkah terakhir yang harus dilakukan oleh setiap satuan pendidikan adalah mengadakan evaluasi keberhasilan. Bagaimana hasil yang telah tercapai selama ini, apakah terdapat perubahan lebih baik dari keadaan sebelumnya, dan lain-lain. (Kemendiknas, 2011).

\section{Kesimpulan dan Saran}

Uraian-uraian di atas bias ditarik kesimpulan bahwa dalam mengatasi dekadensi karakter yang melanda rakyat Indonesia, pemerintah Indonesia melalui Kementerian Pendidikan Nasional telah berupaya untuk mengatasinya, yakni dengan mencetuskan serta mengaplikasikan konsep yang sangat ideal, yaitu Pendidikan Karakter. Bahkan telah memberikan panduan yang sangat rinci bagi seluruh komponen terkait.

Namun demikian, menurut penilaian penulis, usaha 'Pendidikan Karakter' tersebut mungkin dapat terealisasi secara optimal bila mengindahkan beberapa usulan berikut:

1. Memprioritaskan transformasi nilai-nilai agama dan moral sebelum masuk pembahasan pada character building. Hal tersebut dikarenakan, nilai-nilai agama dan moral menjadi syarat mutlak yang harus dimiliki oleh seorang yang 'berkarakter'.

2. Perlunya pendidikan karakter yang aplikatif sehingga tidak hanya terkesan penyampaian teori. Hal tersebut dikarenakan target utama dari Pendidikan Karakter adalah 
pengimplentasian atau pengaplikasian materi Pendidikan Karakter tersebut.

3. Perlunya dukungan dari pemerintah tentang pengadaan program-program yang mendukung untuk terwujudnya maksud serta tujuan pendidikan karakter.

4. Dengan adanya pendidikan karakter seharusnya kebijakan pemerintah tidak memberikan kesan hegemoni sepihak dalam dunia pendidikan di Indonesia. Seperti dalam sikap pembedaan terhadap lembaga pendidikan negeri dan swasta. Adanya Pendidikan Karakter semestinya membuka lebih lebar pintu-pintu teori yang dilahirkan dan dikembangkan oleh seluruh pihak tanpa terkecuali lembaga pendidikan swasta atau lembaga agama dan keagamaan yang ada di Indonesia. Contoh; Lembaga Agama dan Keagamaan Pesantren yang juga berjuang untuk menciptakan generasi bangsa yang berkarakter sesuai dengan karakter yang ditanamkan oleh para leluhur bangsa ini.

5. Program Evaluasi yang berkelanjutan secara merata, baik di lembaga pendidikan ataupun di lingkungan masyarakat.

Demikian begitu pentingnya Pendidikan Karakter dalam rangka untuk mengembalikan jati diri bangsa serta mengarahkan kehidupan orientasi kehidupan bangsa. Sebenarnya program pendidikan karakter ini adalah tanggung jawab setiap individu bangsa Indonesia. Pada akhirnya, mari kita buktikan bahwa kita adalah bangsa yang hebat dan bermartabat. 


\section{DAFTAR PUSTAKA}

Azimabadi, Badr, Etiquettes of Islam Life. Kuala Lumpur; Adam Publisher and Distributors, 2000.

Departemen Pendidikan Nasional, Kamus Besar Bahasa Indonesia. Jakarta; Pusat Bahasa Depdiknas, 2008.

Koentjaraningrat, Kebudayaan Mentalitas dan Pembangunan, Jakarta; Gramedia, 2002.

Kopertais IV, Pendidikan Karakter, Surabaya. Kopertais IV Press, 2012

Kemendiknas, Panduan Pelaksanaan Pendidikan Karakter. Jakarta: Badan Penelitian dan Pengembangan \& Pusat kurikulum dan Perbukuan, 2011.

Mangunwijaya, YB., Impian dari Yogyakarta. Ed. St. Sularto. Yogyakarta: Kompas, 2005. 